\title{
BYRON'S ODE TO NAPOLEON
}

\author{
BY ROBERT F. PACK
}

Dr. Pack is an assistant professor in the Douglass College English Department

J. WISE wrote in A Byron Library (London, I 928), p. 45,
that "Of all the Byron pamphlets published by John Mur-
ray in octavo size the Ode to Napoleon is by far the rarest. It is now almost impossible to find a copy in the original printed paper wrappers." The Rutgers University Library recently acquired a first edition of the poem, not in the original wrappers but bound together with eight other Byron octavo pamphlets.* The volume is an important addition to the University's Byron holdings (which include a ninth edition of the Ode to Napoleon). Collecting Byron editions is often difficult, but for somewhat paradoxical reasons. Although most of the poems were published in large editions making it relatively easy to find the important texts, the poems went through so many editions that it is extremely difficult to accumulate anything like a complete set. The Ode to Napoleon, for instance, appeared in thirteen editions between I8I4 and I8 I 8. Byron's habit of making corrections during press runs further complicates the situation. The history of the Ode is representative of Byron's publishing habits.

In early I 8I4 Byron resolved to cease publishing, but the fall of Napoleon caused him to break his resolution. Despite the importance of the event, Byron speaks condescendingly of the poem that the event produced. On April Io, I 8 I 4 (the day before Napoleon's abdication), Byron wrote his publisher Murray that he had "written an Ode on the fall of Napoleon, which, if you like, I will copy out, and make a present of. . . . You may show it to Mr. Gifford, and print it, or not, as you please-it is of no consequence." But later that same day he again wrote Murray, this time speaking of the poem less cavalierly: "It will be best not to put my name to our Ode; but you may say as openly as you like that it is mine, and I can inscribe it to Mr. Hobhouse from the author, which will mark it sufficiently. ... we will incorporate it in the first tome of ours that you find time or the wish to publish." As Byron requested, the poem was published anonymously, but Murray sufficiently identified the author by insert-

* The book was presented by Harry E. Bernstein '33, and the Ode was called to my attention by Francis A. Johns, who discovered it. 


\section{O D E}

To

\section{NAPOLEON BUONAPARTE.}

"Expende Annibalem :-quot libras in duce summo

"Invenies?

Jovexsl, Sat. $\mathbf{X}$

\section{LONDON:}

PRINTED FOR JOHN MURRAY, ALBEMARLE-STREET, BX W. BULMER AND CO. CLEVELAND-ROW, ST. JAMES'S. 1814. 
ing an advertisement for four recently published works by Byron following the text of the poem. The Ode was widely attributed to Byron, which accounts in part for the frequent editions (ten editions in I 8 I 4 alone). Byron's name first appears on the title page of the tenth edition.

The first two editions of the Ode to Napoleon contain fifteen nineline stanzas. For the third edition Byron inserted a stanza after stanza four in order to increase the number of pages to sixteen. The reasons for the addition are practical rather than aesthetic. Tom Moore, in his Life of Byron (London, I 830), I, 546, provides background on the change: "Mr. Murray had requested of him to make some additions to the Ode, so as to save the stamp duty imposed upon publications not exceeding a single sheet. . . "The sixteen stanza version of the poem was reprinted until the I $83 \mathrm{I}-32$ Murray edition of the Works, in which three additional stanzas were added to the end of the poem on the authority of Moore, who said Byron had intended them for the $O d e$. It is the nineteen stanza version which is currently reprinted popularly.

The text of the recently acquired Ode to Napoleon is identical to a first edition held by the Princeton University Library. Although there are no textual variants, several interesting printing variants exist. The perfection of pp. 7-8 varies in the two copies, and the variation is not one that appears systematically throughout the text. On closer examination, it appears likely that the type for at least part of p. 8 was reset. The spacing between the stanza number III and the first line of the stanza differs in the two copies. This, combined with the variation of the perfection, suggests that the type for p. 8 was disturbed, probably accidentally, and reset with slightly different spaces. The paper of the two copies differs slightly in texture, and the Rutgers copy took the print slightly more clearly. These variations between the two copies, while not sufficient to indicate different issues, represent at least a physical difference of the type within the same edition. It is impossible to conclude which of the two copies was printed first, although the perfection of pp. 7-8 in the Rutgers copy is in superior alignment. The title page and collation of the first edition of the Ode to Napoleon are as follows:

ODE / TO / NAPOLEON BUONAPARTE. / "Expende Annibalem: -quot libras in duce summo / "Invenies? - / JUVENAL, Sat. X. / LONDON: / PRINTED FOR JOHN MURRAY, ALBEMARLE- 
STREET, / BY W. BULMER AND CO. CLEVELAND-ROW, / ST. JAMES'S. / I 8 I4.

Collation: Demy octavo, [A I-I6]; consisting of Half-title (with blank verso) $\left[\begin{array}{ll}A & \text { I-2 }\end{array}\right]$; Title, as above (with blank verso) [A 3-4]; a nine-line extract from Gibbon's Decline and Fall (with blank verso) [A 5-6]; text of the Ode [A 7-I4]; an advertisement for four of Byron's poems, with the imprint "London: Printed by W. Bulmer and Co. / Cleveland-Row, St. James's." at the foot (with blank verso) [A I 5-16]. There are no head lines, and the pages are numbered centrally at head within brackets in Arabic numerals.

The volume of which the Ode to Napoleon is a part includes seven other octavo pamphlets. The pamphlets, bound under boards and cut to a uniform $81 / 4$ " $\times 5$ ", probably represent an individual's private collection. The range of dates of the pamphlets, from I8I4 to I 8I8, suggests that they came from a private library. Had the pamphlets been bound by Murray or with his copies of the poems, presumably the latest editions of the pamphlets would have been used. The volume could not have been bound before 18 I 8 , the date of the third edition of Beppo. A binder's insertion, following The Lament of Tasso consisting of six pages, four pages of advertisements for books published by Murray (numbered I-2, I I-I2) and a page containing advertisements for fourteen Byron poems, is dated August, I 817 . The binder's end paper is dated with the watermark CMD / I8I6. This appears to be a unique volume.

All the title pages of the eight pamphlets are intact, making identification of the editions possible. My identifications are based upon the descriptions furnished by T. J. Wise in his Bibliography of the Writings in Verse and Prose of George Gordon Noel, Baron Byron, 2 vols. (London, I932). The volume contains the following octavo pamphlets: Beppo, 3rd edition ( I 8 I 8); Mazeppa, rst edition, 2nd issue (1817); The Lament of Tasso, 5th edition ( I 817); Monody on the Death of Sheridan, Ist edition, 2nd issue (I 8 I6); Poems (I 8I6), Ist edition (I8I6); Hebrew Melodies, Ist edition, issue number unknown because Sig. E 4 is missing (I 8 I 5 ); Ode to Napoleon Buonaparte, Ist edition (I8I4); The Prisoner of Chillon, and Other Poems, rst edition, issue number unknown because Sig. E 8 is missing ( 1816 ). In both cases, the missing signatures containing the variant consist only of advertisements. The volume entitled on the spine Ld. Byron's Poems represents a significant addition to the Byron holdings. 